\title{
Expression of Fibroblast Growth Factor 1 (FGF1) and FGF7 in Mature Follicles during the Periovulatory Period after GnRH in the Cow
}

\author{
Bajram BERISHA ${ }^{1)}$, Harald WELTER ${ }^{1) \#}$, Takashi SHIMIZU ${ }^{2)}$, \\ Akio MIYAMOTO ${ }^{2)}$, Heinrich H.D. MEYER ${ }^{1)}$ and Dieter SCHAMS ${ }^{1)}$ \\ 1)Institute of Physiology Weihenstephan, Technical University of Munich, 85350 Freising- \\ Weihenstephan, Germany, ${ }^{2)}$ Graduate School of Animal and Food Hygiene, Obihiro \\ University of Agriculture and Veterinary Medicine, Obihiro, Japan \\ \#Present: Institute of Animal Husbandry and Regulation Physiology, University of Hohenheim, \\ D-70593 Stuttgart, Germany
}

\begin{abstract}
The aim of this study was to evaluate the expression pattern of mRNA for fibroblast growth factor 1 (FGF1), FGF7, and their receptor variants (FGFR2IIIb) in time-defined follicle classes before LH surge, between LH surge and ovulation, and in the early corpus luteum (CL) in the cow. The ovaries were collected by transvaginal ovariectomy ( $n=5$ cows/group), and the follicles ( $n=5$, one follicle/cow) were classified into the following groups: before GnRH administration (before LH surge); 3-5 h after GnRH (during LH surge); 10 h after GnRH; 20 h after GnRH; 25 h after GnRH (periovulation), and early CL (Days 2-3). The mRNA expression was analyzed by quantitative realtime PCR (RotorGene 3000). The mRNA expression of FGF1 showed no significant differences in the follicle groups examined, but increased significantly at the early CL phase. A transient increase in FGF7 mRNA expression was observed 3-5 h after GnRH and again in the early CL phase. In contrast, the expression of FGFR2IIIb was constant throughout the period from the final growth of the follicle to early CL formation. The results of this study suggest that FGF1 and FGF7 may be involved differently in the process of follicle maturation and CL formation, which is strongly dependent on angiogenesis. Key words: Corpus luteum, Cow, FGF1, FGF7, Follicle, LH surge
\end{abstract}

(J. Reprod. Dev. 52: 307-313, 2006)

$\mathbf{T}$ he fibroblast growth factor (FGF) family consists of at least 23 different signalling polypeptide members, which are characterized by a core region with a highly conserved sequence and structure [1]. FGFs are necessary for many biological processes and induce mitogenic, chemotactic, and angiogenic activity in a wide variety of cell and tissue types. Acidic FGF (FGF1), basic FGF (FGF2), and FGF7 (keratinocyte growth

Accepted for publication: December 9, 2005

Published online: January 16, 2006

Correspondence: B. Berisha (e-mail: physio@wzw.tum.de) factor) are prototypic members of this large family that regulate ovarian function as a potential angiogenic factor [2-8]. FGF1 mRNA and protein have been found in the rat [9], ovine [10], and bovine $[8,11]$ ovary. FGF7 is mainly produced and secreted by theca cells, and granulosa cells express its receptor [8]. Therefore, it is possible that FGF7 is a paracrine hormone within the ovarian follicle.

FGF family members mediate their biological activities through high affinity tyrosine kinase receptors (FGFR1 to FGFR4) [12]. FGF receptors are characterised by the presence of two or three 


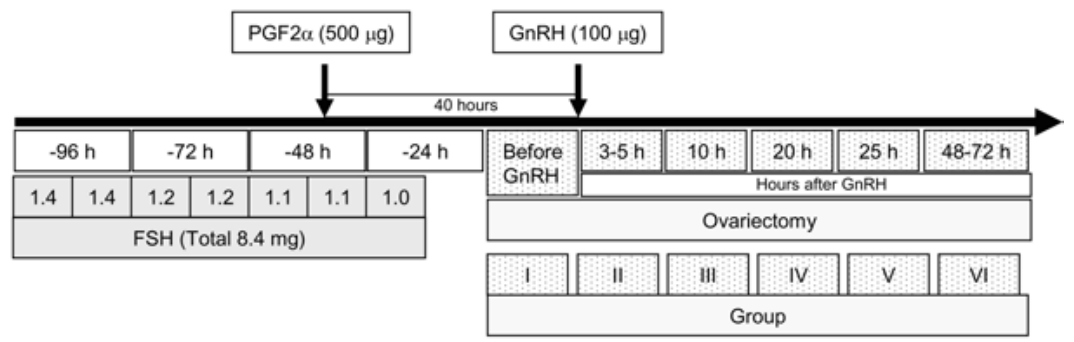

Fig. 1. Time schedule of treatment for multiple ovulation and ovariectomy in cows. Groups: (I) follicle before GnRH administration (before LH surge); (II) 3-5 h after GnRH administration (during LH surge); (III) $10 \mathrm{~h}$ after GnRH; (IV) $20 \mathrm{~h}$ after GnRH, (V) $25 \mathrm{~h}$ after GnRH (peri-ovulation); and (VI) early phase CLs (Days 2-3).

immunoglobulin-like domains in the extracellular region and a tyrosine kinase domain in the intracellular region of the receptor. Alternative splicing in the extracellular region of FGFR1 to FGFR3 generates receptor variants (IIIb and IIIc) with different ligand binding affinities and tissue specific profiles of expression $[8,12]$. Although all the different splice variants of the four FGFRs are activated by FGF1, most of the FGFR variants have narrower specificity for the different FGF ligands. In particular, FGF7 is primarily localized on epithelial cells $[13,14]$, and activates the splice variant FGFR2IIIb [15].

Recently, it has been shown that FGF family members and their receptors are involved in the formation of capillaries that accompany selection of the pre-ovulatory follicle [8]. However, the expression pattern of FGF1, FGF7 and FGFR2IIIb in the process of follicular maturation and corpus luteum (CL) formation in the bovine ovary is still unknown. It would be valuable, in terms of a better understanding of angiogenic regulation in dominant follicles and the $\mathrm{CL}$, to investigate the mRNA expression of FGF1, FGF7, and FGFR2IIIb. Therefore, we investigated the mRNA expression of these factors in relation to periovulatory phase dominant follicles (before and after LH surge) and of early stage CLs.

\section{Materials and Methods}

\section{Animals and superovulation}

The experimental protocol was approved by the institutional care (AZ 211-2531.3-33/96) and use committee. The study was conducted on 30 non- lactating German Fleckvieh cows. The cows were induced to have multiple follicles (for different experimental purposes) by administration of a reduced dose ( $8.4 \mathrm{mg}$ in total) of follicle stimulating hormone (FSH; Ovagen, ImmunoChemical Products Ltd., Auckland, New Zealand). The time schedule scheme for the superovulatory treatment and ovariectomy is shown in Fig. 1. FSH injections (in total seven) were given i.m. at $12 \mathrm{~h}$ intervals in gradually decreasing doses for 3.5 days, starting between days 8 and 11 of the oestrous cycle. After the sixth FSH injection, a luteolytic dose of $500 \mu \mathrm{g}$ of $\mathrm{PGF}_{2 \alpha}$ analogue, Estrumate (Cloprostenol; BERNA Veterinärprodukte AG, Bern, Switzerland) was injected i.m., and then $40 \mathrm{~h}$ after injection, 100 $\mu \mathrm{g}$ of GnRH (Receptal; BERNA Veterinärprodukte AG, Bern, Switzerland), was injected to induce LH surge. The ovaries were collected by transvaginal ovariectomy ( $\mathrm{n}=5$ cows/group).

\section{Collection, classification and preparation of follicles and $C L$}

Follicles ( $\mathrm{n}=5$, one follicle/cow) collected by transvaginal ovariectomy (5 cows/group) were classified into the following groups: (I) before GnRH administration (control, before LH surge); (II) 3-5 h after GnRH administration (during LH surge); (III) $10 \mathrm{~h}$ after GnRH; (IV) $20 \mathrm{~h}$ after GnRH; (V) $25 \mathrm{~h}$ after GnRH (peri-ovulation); and (VI) early CL (Days 2-3). An LH surge was induced 3-5 h after $\mathrm{GnRH}$ administration.

Only follicles that appeared to be healthy (i.e. well vascularised and having transparent follicular wall and fluid) and that had a diameter of $>10 \mathrm{~mm}$ were collected. The number of follicles per ovary varied between $8-20$. For RNA extraction, the 
Table 1. Primer sequences and product size (bp) of FGF1, FGF7, FGFR2IIIb, ubiquitin (UBQ), and glycerolaldehyde-3-phosphate-dehydrogenase (GAPDH)

\begin{tabular}{|c|c|c|c|}
\hline Genes & Nucleotide of sequence* & Size (bp) & References** \\
\hline \multirow[t]{2}{*}{ FGF1 } & For 5'-GCTGAAGGAGAAACCACGAC-3' & \multirow[t]{2}{*}{317} & \multirow[t]{2}{*}{ [8] } \\
\hline & Rev 5'-GTTTTCCTCCAАССТTТCCA -3' & & \\
\hline \multirow[t]{2}{*}{ FGF7 } & For 5'-CTGCCAAGTTTGCTCTACAG-3' & \multirow[t]{2}{*}{294} & \multirow[t]{2}{*}{ [8] } \\
\hline & Rev 5'-TCCAACTGCCAGGGTCCTGAT-3' & & \\
\hline \multirow[t]{2}{*}{ FGFR2IIIb } & For 5'-TGGAGAATGAATACGGGT CC-3' & \multirow[t]{2}{*}{298} & \multirow[t]{2}{*}{ [8] } \\
\hline & Rev 5'-TCGGTCACATTGAACAGAGC-3' & & \\
\hline \multirow[t]{2}{*}{ UBQ } & For 5'-ATGCAGATCTTTGTGAAGAC-3' & \multirow[t]{2}{*}{189} & \multirow[t]{2}{*}{ [8] } \\
\hline & Rev 5'-CTTCTGGATGTTGTAGTC-3' & & \\
\hline \multirow[t]{2}{*}{ GAPDH } & For 5'-GTCTTCACTACCATGGAGAAGG-3' & \multirow[t]{2}{*}{197} & \multirow[t]{2}{*}{ [25] } \\
\hline & Rev 5'-TCATGGATGACCTTGGCCAG-3' & & \\
\hline
\end{tabular}

${ }^{*}$ : For, forward; Rev, reverse. ${ }^{*}$ : Reference of the published sequence.

follicles were dissected from the ovary. The surrounding tissue (theca externa) was removed with forceps under a stereomicroscope. All follicles were aliquoted, quickly frozen in liquid nitrogen, and stored at $-80 \mathrm{C}$ until RNA extraction. Follicular fluid (FF) was aspirated from the follicles and stored at $-20 \mathrm{C}$ until assayed. Progesterone $(\mathrm{P})$, oestradiol-17 $\beta\left(\mathrm{E}_{2}\right), \mathrm{PGF}_{2 \alpha}$, and $\mathrm{PGE}_{2}$ were measured for confirmation of follicle classes and comparison with spontaneous growing preovulatory follicles.

\section{Isolation of RNA}

Total RNA was prepared from follicular and CL tissue according to the method of Chomczynski \& Sacchi [16] with TriPure ${ }^{\circledR}$ isolation reagent (Roche Diagnostics, Mannheim, Germany) as described previously in detail [17]. Possible DNA contaminations were eliminated by an additional DNase digestion, according to the manufacture's protocol (Promega, Madison, WI, USA). Total RNA was purified using NucleoSpin ${ }^{\circledR}$ RNA II (Macherey \& Nagel, Düren, Germany), with the concentration and purity being determined spectroscopically at an absorbance of $260 \mathrm{~nm}$ using a Biophotometer (Eppendorf, Hamburg, Germany). Aliquots (1 $\mu \mathrm{g})$ were subjected on $1 \%$ denaturing agarose gel electrophoresis and ethidium bromide staining to verify the quantity and quality of the total RNA.

\section{Reverse transcription}

Total RNA was reverse transcribed to cDNA in a volume of $60 \mu \mathrm{l}$ containing $1 \mu \mathrm{g}$ RNA, $2.5 \mu \mathrm{mol} / 1$ random hexamers (Gibco BRL, Grand Island, NY), and M-MLV reverse transcriptase $(200 \mathrm{U} / \mu \mathrm{l}$,
Promega, Madison, WI, USA) according to Pfaffl et al. [18]. A minus RT-reaction (the RT-enzyme was replaced by water) was performed to detect residual DNA-contamination.

\section{Conventional PCR (Polymerase Chain Reaction)}

Primers were designed using the EMBL database or used according to the literature (Table 1). Optimal conditions for RT-PCR were evaluated in a gradient thermocycler (Eppendorf, Hamburg, Germany) and amplification was carried out in a 25 $\mu \mathrm{l}$ reaction mixture containing $1.5 \mu \mathrm{l}$ cDNA (25 ng) as described previously [8]. PCR products were separated by $2 \%$ high-resolution NuSieve agarose (FMC BioProducts, Rockland, USA) gel electrophoresis, and band intensities (optical intensity) were analysed using an Image Master system (Amersham-Pharmacia, Freiburg, Germany) as described previously [17]. In order to validate conventional PCR results, the mRNA expression of all factors were also evaluated by real-time RT-PCR.

\section{Real-time RT-PCR (Rotor-Gene $3000^{\mathrm{TM}}$ )}

Quantitative fluorescence real-time RT-PCR analysis was performed [18] using a Rotor-Gene $3000^{\mathrm{TM}}$ system (Corbett Research, Sydney, Australia). Online PCR reactions were carried out using a LightCycler ${ }^{\circledR}$ DNA Master SYBR Green I kit (Roche Diagnostics, Mannheim, Germany) with 1 $\mu \mathrm{l}$ of each cDNA (16.66 ng) in a $10 \mu \mathrm{l}$ reaction mixture $\left(3 \mathrm{mmol} / 1 \mathrm{MgCl}_{2}, 0.4 \mu \mathrm{mol} / 1\right.$ of each forward and reverse primer, $1 \times$ LightCycler $^{\circledR}$ DNA Master SYBR Green I). After initial incubation at 95 $\mathrm{C}$ for $10 \mathrm{~min}$ to activate Taq DNA polymerase, 
templates of all the specific transcripts were amplified for 40 cycles at $95 \mathrm{C}$ for $10 \mathrm{~s}$ followed by annealing at a temperature of $60 \mathrm{C}$ for all primers used, each $10 \mathrm{~s}$, and elongation at $72 \mathrm{C}$ for $15 \mathrm{~s}$. Fluorescence data used for quantitation was acquired at the end of each $72 \mathrm{C}$ elongation step for $5 \mathrm{~s}$ by SYBR Green binding to the amplified dsDNA. Melting curve analysis (Rotor-Gene $3000^{\mathrm{TM}}$ ), by heating at $95 \mathrm{C}$ for $5 \mathrm{~s}$, followed by cooling to $65 \mathrm{C}$ for $5 \mathrm{~s}$, and then continuous heating to $99 \mathrm{C}$ at $0.5 / \mathrm{s}$ under permanent fluorescence detection, and agarose gel analyses were conducted immediately after completion of PCR to verify single product formation.

Relative quantification analysis was performed with the Rotor-Gene software (version 5.03) using a dynamic amplification efficiency determination for each amplification run as provided in the comparative quantification method. The number of cycles for each sample was determined using the take-off point, which is automatically calculated by the Rotor-Gene software. The data was analyzed using the Rotor-Gene $3000^{\circledR}$ software (version 5.03). The changes in mRNA expression of the examined factors were assayed by normalization to the ubiquitin internal control. In order to obtain the CT (cycle threshold) difference, the data was analysed using the $\Delta \Delta C T$ method described previously [19], with $\Delta \mathrm{CT}=\mathrm{CT}_{\text {target }}-\mathrm{CT}_{\text {ubiquitin }}$ and $\Delta \Delta \mathrm{CT}=\Delta \mathrm{CT}_{\text {(group I, }}$ as control) $-\Delta C \mathrm{~T}_{\text {(group II-VI). }}$ The statistical analyses were based upon $\Delta C T$ values $(n=5)$. Expression changes $(\Delta \Delta C T)$ for the different groups were defined as the relative expression (CT) compared with follicle group I (as control). As PCR amplification is a process with exponential characteristics, a $\Delta \Delta \mathrm{CT}$ difference denotes a shift in regulation by a factor of two $\left(2^{\Delta \Delta C T}\right)$.

\section{Statistical analyses}

The statistical significance of differences in examined factors were analyzed by ANOVA followed by Fisher's protected least significant difference test. All experimental data are shown as the mean \pm SEM. Follicles and CLs $(n=5)$ were obtained from 5 cows per group.

\section{Results}

\section{Confirmation of primer specificity and sequence analysis}

The mRNA expression was analysed by block (conventional) and real-time RT-PCR (RotorGene 3000). Initial RT-PCR experiments verified specific transcripts for all examined factors in the bovine follicles and CLs. For exact length verification, RTPCR products were separated by $2 \%$ highresolution agarose gel electrophoresis. PCR products were verified by subcloning the cDNA into a transcription vector (PCR-Script, Stratagene, La Jolla, CA, USA), followed by commercial DNA sequencing (TopLab, Munich, Germany). Each PCR product (Table 1) showed $100 \%$ homology to the known bovine genes after sequencing.

\section{Expression of $m R N A$}

To confirm the integrity of the mRNA templates and RT-PCR protocol, the housekeeping genes ubiquitin (UBQ) and glycerolaldehyde-3phosphate dehydrogenase (GAPDH) were examined in all samples. The mRNA expression of these housekeeping genes in all samples resulted in constant expression levels.

The conventional and real-time PCR (RotorGene 3000) experiments revealed no differences in the mRNA expression patterns. Therefore, in this study, we present only mRNA expression data from real-time PCR. The results of mRNA expression for the examined factors (Fig. 2) are presented as changes $(\Delta \Delta \mathrm{CT} \pm \mathrm{SEM}$ from 5 follicles or CLs per group) in the target gene expression, normalized to UBQ and relative to group I (control). The mRNA signal for FGF1 showed no significant differences in the follicle groups examined. The FGF1 mRNA expression only increased significantly (Fig. 2a) after ovulation (in the early CL phase). FGF7 mRNA expression was significantly upregulated during the LH surge and down-regulated again shortly afterwards. A further significant up-regulation occurred after ovulation (Fig. 2b). In contrast, mRNA levels of FGFR2IIIb did not change significantly in either follicles between the LH surge and ovulation or in early phase CLs (Fig. 2c). 

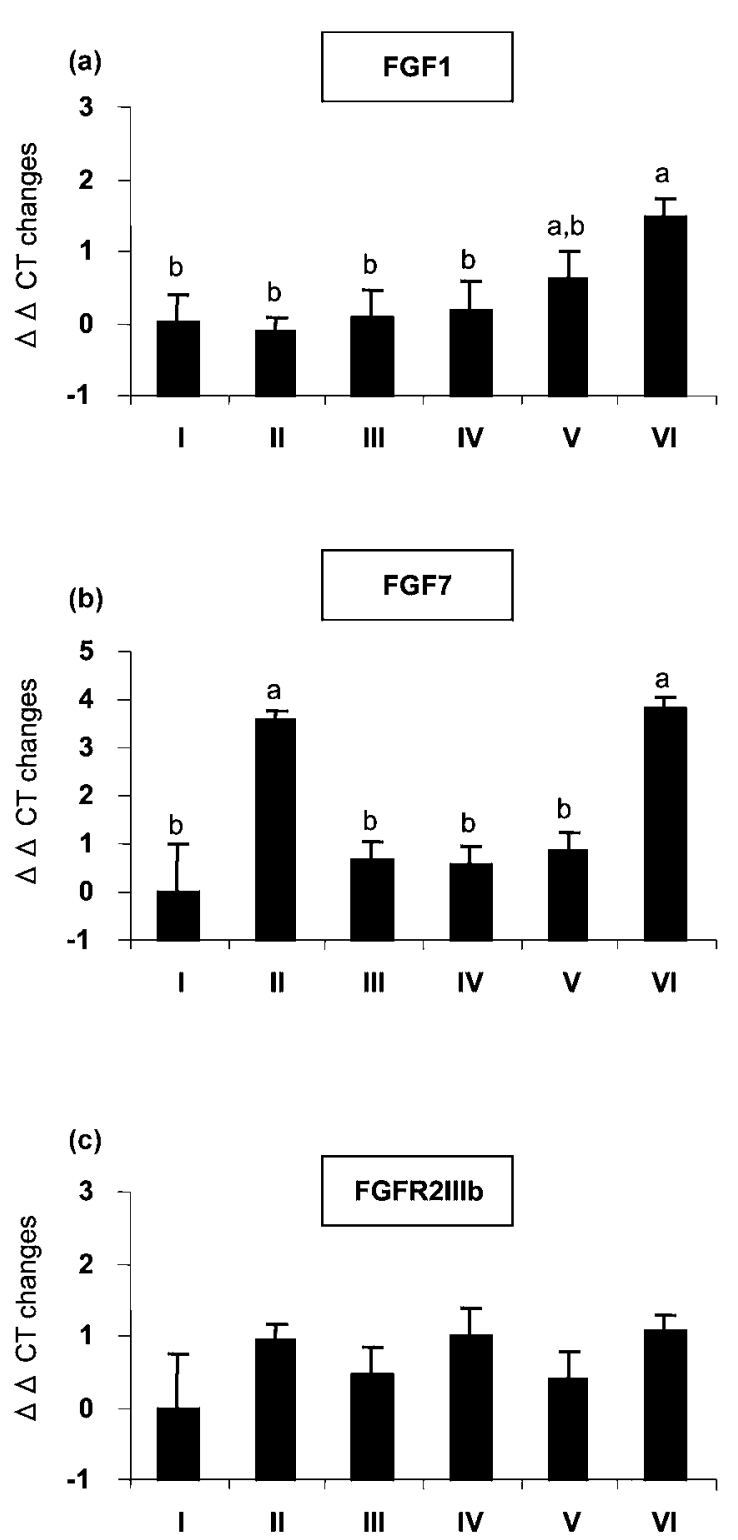

Fig. 2. Expression of mRNA for (a) FGF1, (b) FGF7 and (c) FGFR2IIIb in bovine follicle tissue and early phase CLs. (I) Before GnRH administration (before LH surge); (II) 3-5 h after GnRH administration (during LH surge); (III) $10 \mathrm{~h}$ after GnRH; (IV) $20 \mathrm{~h}$ after GnRH; (V) 25 h after GnRH (peri-ovulation); and (VI) early phase CLs (Days 2-3). Changes in mRNA expression for the different groups were calculated relative to the follicle group I (before $\mathrm{GnRH}$ application, as control) as the previously described by Livak and Schmittgen (2001), with $\Delta \mathrm{CT}=\mathrm{CT}_{\text {target }}{ }^{-}$ $\mathrm{CT}_{\text {ubiquitin }}$ and $\Delta \Delta \mathrm{CT}=\Delta \mathrm{CT}_{\text {(group I=control) }}-\Delta \mathrm{CT}_{\text {(group II-VI) }}$. The statistic analyses were based upon $\Delta \mathrm{CT}$ values $(n=5)$. Results are presented as expression changes ( $\triangle \triangle \mathrm{CT} \pm$ SEM from 5 follicles or CLs per group) in the target gene expression, normalized to UBQ and relative to group I (control). Different superscripts denote statistically different values $(\mathrm{P}<0.05)$.

\section{Discussion}

The present study indicated that the expression of FGF1 mRNA increased only at the early CL phase, whereas FGF7 expression transiently increased 3-5 h after $\mathrm{GnRH}$ and again in the early phase CL. Since FGF7 expression is observed in the theca interna but not granulosa cells [8], the results of the present study indicates that expression of FGF7 mRNA is of theca interna cell origin. It is generally accepted that FGF1 and FGF7 are important factors for angiogenesis [8, 20]. After ovulation, definitive structural and functional changes dramatically occur, with the resultant growth and vascularization of the ovulated follicles transforming them into CL [21]. Therefore, our data suggest that FGF1 and FGF7 may be associated with angiogenesis for CL formation as well as follicular maturation toward ovulation. The results of the present study showed a transient increase in FGF7 3-5 h (during the LH surge) after GnRH treatment. Vascular endothelial growth factor (VEGF) and angiopoietins are known to be associated with follicular development and perifollicular capillary network changes during the LH surge. A recent study demonstrated that expression of angiopoietin-2 mRNA increased during the preovulatory period and ovulation in eCG/hCG-treated rats [22]. Since angiopoietin-2 acts on the destabilization of blood vessels, FGF7 may be associated with initiation of vascular formation to form the early phase CL.

The LH receptor mRNA is expressed in the theca interna cells of antral follicles in the bovine ovary. During follicular growth, the level of LH receptor mRNA expression increases with follicle size [23]. The present study demonstrated that expression of FGF7 mRNA increased 3-5 h after GnRH treatment, indicating that expression of FGF7 may be regulated by LH. Future studies are needed to examine the effect of LH on FGF7 expression in bovine theca interna cells using a cell culture system.

In this study, the expression of FGF1 and FGF7 mRNA increased in the early phase CL. At the time of ovulation, as the follicle is converted into a CL, the changes in the vascular network surrounding the mature follicle are remarkable. The capillary plexus adjacent to the basement membrane expands by 'sprouting' into the avascular granulosa layer to form a dense network of 
sinusoidal capillaries. The outer capillary plexus delays sprouting until about 24 hours after ovulation, but becomes interconnected in the $\mathrm{CL}$ with the first network capillaries [24]. Therefore, the results of the present study suggest that FGF1 and FGF7 are associated with vascular formation in the early phase CL.

Our present data showed that expression of FGFR2IIIb is constant throughout the period from final maturation of the follicle to early phase CL formation. Constant expression of FGFR2IIIb implies that this gene is not affected by LH surge or LH surge-induced factors.

In conclusion, the present study suggests that the different mRNA levels of FGF1 and FGF7 may be implicated in different functions in relation to angiogenesis during follicle maturation, ovulation, and CL formation.

\section{Acknowledgements}

We greatly acknowledge the support of the German Research Foundation (DFG, Scha 257/14-2 and BE 3189/1-3). This study was supported by the 21st Century COE program (A-1) of Ministry of Education, Culture, Science and Technology of Japan, and by a Grant-in-Aid for Scientific Research of the Japan Society for the Promotion of Science (JSPS).

\section{References}

1. Ornitz DM, Itoh N. Fibroblast growth factors. Genome Biol 2001; 2: 1-12.

2. Gospodarowicz D, Ferrara N, Schweigerer L, Neufeld G. Structural characterization and biological functions of fibroblast growth factor. Endocr Rev 1987; 8: 95-114.

3. Schams D, Amselgruber W, Einspanier R, Sinowatz F, Gospodarowicz D. Localization and tissue concentration of basic fibroblast growth factor in the bovine corpus luteum. Endocrine 1994; 2: 907912.

4. Parrott JA, Skinner MK. Developmental and hormonal regulation of keratinocyte growth factor expression and action in the ovarian follicle. Endocrinology 1998; 139: 228-235.

5. Salli U, Bartol FF, Wiley AA, Tarleton BJ, Braden TD. Keratinocyte growt factor expression by the bovine corpus luteum. Biol Reprod 1998; 59: 77-83.

6. Berisha B. Angiogenic factors in the bovine ovary. In: Technical University Munich. Herbert Utz Verlag, Munich; 2001; Thesis 1-89.

7. Nilsson E, Parrott JA, Skinner MK. Basic fibroblast growth factor induces primordial follicle development and initiates folliculogenesis. Mol Cell Endocrinol 2001; 175: 123-130.

8. Berisha B, Sinowatz F, Schams D. Expression and localization of fibroblast growth factor (FGF) family members during the final growth of bovine ovarian follicles. Mol Reprod Dev 2004; 67: 162-171.

9. Koos RD, Olson CE. Expression of basic fibroblast growth factor in the rat ovary: detection of mRNA using reverse transcription-polymerase chain reaction amplification. Mol Endocrinol 1989; 3: 20412048.

10. Jablonka-Shariff A, Grazul-Bilska AT, Redmer DA, Reynolds P. Cellular proliferation and fibroblast growth factors in the corpus luteum during early pregnancy in ewes. Growth Factors 1997; 14: 15-23.

11. Zheng J, Redmer DA, Reynolds LP. Vascular development and heparin-binding growth factors in the bovine corpus luteum at several stages of the estrous cycle. Biol Reprod 1993; 49: 1177-1189.

12. Powers CJ, McLeskey SW, Wellstein A. Fibroblast growth factors, their receptors and signaling. Endocr Relat Cancer 2000; 7: 165-197.

13. Bottaro DP, Rubin JS, Ron D, Finch PW, Florio C, Aaronson SA. Characterization of the receptor for keratinocyte growth factor. Evidence for multiple fibroblast growth factor receptors. J Biol Chem 1990; 265: 12767-12770.

14. Rubin JS, Bottaro DP, Chedid M, Miki T, Ron D, Cheon HG, Taylor WG, Fortney E, Sakata H, Finch PW, LaRochelle WJ. Keratinocyte growth factor. Cell Biol Int 1995; 19: 399-411.

15. Ornitz DM, Xu J, Colvin JS, McEwen DG, MacArthur CA, Coulier F, Gao G, Goldfarb M. Receptor specificity of the fibroblast growth factor family. J Biol Chem 1996; 271: 15292-15297.

16. Chomczynski P, Sacchi N. Single-step method of RNA isolation by acid guanidinium thiocyanatephenol-chloroform extraction. Anal Biochem 1987; 162: 156-159.

17. Berisha B, Schams D, Kosmann M, Amselgruber W, Einspanier R. Expression and localization of vascular endothelial growth factor (VEGF) and basic fibroblast growth factor (FGF-2) during the final growth of bovine ovarian follicles. J Endocrinol 2000; 167: 371-382.

18. Berisha B, Meyer HHD, Schams D. The expression of fibroblast growth factor (FGF) family members in bovine follicles during peri-ovulatory phase. Vet 
Med Austria/Wien Tierärztl Mschr 2004; 91 (Suppl 2): 10-11.

19. Livak KJ, Schmittgen TD. Analysis of relative gene expression data using real-time quantitative PCR and the 2(-Delta Delta C(T)) Method. Methods 2001; 25:402-408.

20. Gillis P, Savla U, Volpert OV, Jimenez B, Waters CM, Panos RJ, Bouck NP. Keratinocyte growth factor induces angiogenesis and protects endothelial barrier function. J Cell Sci 1999; 112: 2049-2057.

21. Redmer DA, Doraiswamy V, Bortnem BJ, Fisher K, Jablonka-Shariff A, Grazul-Bilska AT, Reynolds LP. Evidence for a role of capillary pericytes in vascular growth of the developing ovine corpus luteum. Biol Reprod 2001; 65: 879-889.

22. Miyabayashi K, Shimizu T, Kawauchi C, Sasada H, Sato E. Changes of mRNA expression of vascular endothelial growth factor, angiopoietins and their receptors during the periovulatory period in eCG/ hCG-treated immature female rats. J Exp Zool Part A 2005; 303: 590-597.

23. Xu Z, Garverick HA, Smith GW, Smith MF, Hamilton SA, Youngquist RS. Expression of follicle-stimulating hormone and luteinizing hormone receptor messenger ribonucleic acids in bovine follicles during the first follicular wave. Biol Reprod 1995; 53: 951-957.

24. Hazzard TM, Stouffer RL. Angiogenesis in ovarian follicular and luteal development. Baillieres Clin Obstet Gynaecol 2000; 14: 883-900.

25. Berisha B, Pfaffl MW, Schams D. Expression of estrogen and progesterone receptors in the bovine ovary during estrous cycle and pregnancy. Endocrine 2002; 17: 207-214. 